\title{
ANALISIS KELAYAKAN DAN PENGEMBANGAN USAHA MINUMAN JELLY DRINK "MICHU" DENGAN ASPEK FINANSIAL PADA UKM DAPUR GADIS PAMULANG BARAT
}

\author{
Sri Utaminingsih ${ }^{1)}$, Rini Alfatiyah ${ }^{1)}$, Dewi Mawarsari ${ }^{2)}$ \\ ${ }^{1)}$ Dosen Teknik Industri Universitas Pamulang \\ ${ }^{2}$ Mahasiswa Teknik Industri Universitas Pamulang
}

\begin{abstract}
ABSTRAK
Para pelaku Usaha Kecil Menengah memberikan kontribusi terhadap berkembangnya industri perumahan. Penelitian ini dilaksanakan pada usaha minuman Jelly Drink UKM Dapur Gadis Michu di Pamulang Barat Kota Tangerang Selatan. Variabel yang digunakan dalam penelitian ini adalah seperti permodalan, teknologi, pemasaran, akses informasi pasar dan sebagainya. Tujuan dari penelitian ini untuk mengetahui kelayakan dan untuk mengetahui strategi pengembangan sektor industri kecil minuman Jelly Drink Michu di UKM Dapur Gadis Pamulang Barat. Analisis kelayakan menggunakan perhitungan finansial dan perbandingan Net Benefit Cost Ratio (BCR). Untuk itu diharapakan dalam penelitian ini memberikan beberapa masukan berdasarkan aspek dalam studi kelayakan sehingga dalam melaksanakan usaha dalam bidang minuman Jelly Drink Michu ini mengetahui kelayakan yang harus dipenuhi dan dijalankan. Hasil analisis Kelayakan finansial industri kecil minuman Jelly Drink Michu di UKM Dapur Gadis Pamulang Barat layak dilakukan. Nilai B/CR adalah sebesar 1,57 layak dilakukan. Nilai ROI adalah sebesar 57\%, layak dilakukan.
\end{abstract}

Kata Kunci: Kelayakan Usaha, Aspek Finansial, UKM

\section{PENDAHULUAN}

\section{A. Latar Belakang}

Usaha kecil dan menengah merupakan bagian dari industri yang memfasilitasi bagi masyarakat yang memulai berdirinya sebuah perusahaan besar. Industri baik dari industri manufaktur maupun dari indutri jasa tentunya harus memiliki inovasi dan kreatif dalam mengelola usahanya. Oleh karena itu untuk mengetahui tentang usaha dapat dianalisa berdasarkan analisa kelayakan usaha. Untuk itu sebelum berinovasi dan melakukan pengembangan usaha yang dijalankan perlu adanya sebuah analisa yang mana dapat mengetahui secara mendalam dan sistematis apakah usaha yang dijalankan layak atau tidaknya. Untuk itu penelitian ini akan menganalisa UKM yang terletak di jalan mede no. 16 RT/RW 3/5, kelurahan Pamulang, Kecamatan Pamulang Barat, Kabupaten Tangerang Selatan Provinsi Banten. Usaha ini dimulai pada bulan September 2018. Namun pada saat itu usaha ini masih melakukan riset dan inovasi dari beberapa masukan konsumen mengenai beberapa hal seperti kemasan, rasa,

dan harga sehingga dalam analisa klayakan dapat mengetahui usaha yang dijalankan. Demi kepuasan konsumen, kami dari mulai awal produksi sampai sekarang selalu berusaha untuk menghasilkan produk minuman yang berkualitas, berdasarkan data penjualan minuman jelly drink dapat dilihat pada diagram pareto berikut:

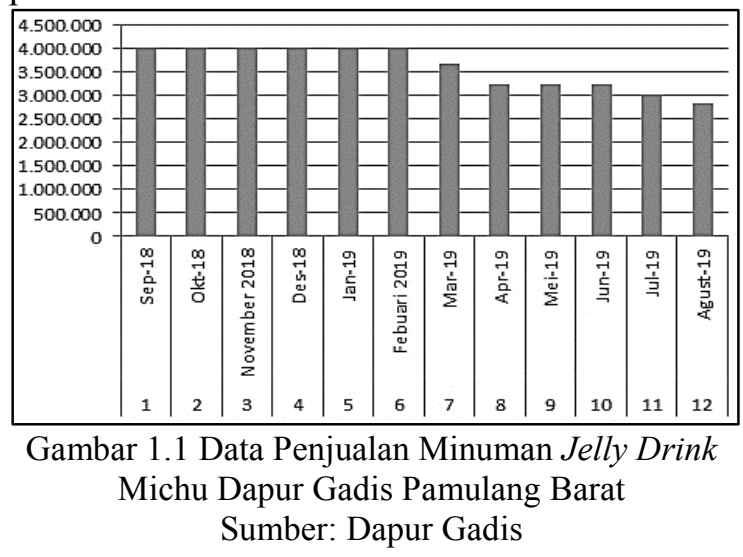


Pada gambar diatas dapat dilihat penurunan penjualan dimulai pada bulan maret 2019-agustus 2019. Hal ini dapat disebabkan dari banyak faktor, diantaranya dari segi finansial, kurangnya modal, kurangnya SDM, dan kurangnya pengetahuan konsumen terhadap produk. Tabel data penjualan ini adalah sebagai faktor pendukung adanya masalah dalam perusahaan. Dalam analisa penelitian ini langkah pertama adalah menentukan apakah usaha ini layak atau tidaknya dengan mencari akar permasalahan dari sumber finansial dengan mencari biaya tetap, biaya variabel kemudian mencari keuntungan dan pendapatan .dan langkah terakhir adalah membandingkan nilai BCR untuk mendapatkan hasil apakah usaha tersebut layak dilaukan atau tidak.

\section{DASAR TEORI}

\section{A. Pengertian Industri Kecil atau Usaha Kecil (Mikro).}

Usaha Kecil Menengah (UKM) adalah salah satu motor penggerak perekonomian di Negara kita, usaha mikro kecil, dan menengah (UMKM) merupakan tulang punggung perekonomian di Indonesia. UKM menurut Suhardjono dalam Rafika (2010) mendefinisikan Usaha Kecil adalah kegiatan ekonomi rakyat yang berskala kecil, dan memenuhi kriteria kekayaan bersih atau hasil penjualan tahunan serta kepemilikan sebagaimana diatur dalam undang-undang. Kriteria perusahaan di Indonesia dengan jumlah tenaga kerja 1-4 orang sebagai usaha rumah tangga, perusahaan dengan tenaga kerja 5-19 sebagai usaha kecil, perusahaan dengan jumlah tenaga kerj 20-99 sebagai industri menengah, dan perusahaan dengan tenaga kerja lebih dari 100 orang sebagai usaha besar.

\section{B. Pengertian Analisa Kelayakan Usaha}

Menurut Umar (2015), analisis kelayakan usaha merupakan penelitian terhadap rencana bisnis yang tidak hanya menganalisis layak atau tidak layak bisnis dibangun, tetapi juga saat dioperasionalkan secara rutin dalam rangka pencapaian keuntungan yang maksimal untuk waktu yang tidak ditentukan. Dengan demikian, dapat disimpulkan bahwa studi kelayakan usaha ini merupakan suatu kegiatan analisis yang dilakukan untuk menilai layak atau tidak layaknya usaha bisnis dijalankan dalam rangka mencapai tujuan yang diinginkan. Analisis Kelayakan Usaha merupakan langkah awal yang menjadi titik acuan dalam memutuskan pembangunan sebuah usaha. Kegiatannya mempelajari secara mendalam tentang usaha yang akan dijalankan, untuk menentukan layak atau tidaknya suatu bisnis dijalankan.

\section{Tujuan Analisa Kelayakan Usaha}

Tujuan dilakukannya Analisa Kelayakan Usaha (Gray dan Larson, 2007) adalah:

1. Untuk mengetahui tingkat keuntungan yang dapat dicapai melalui investasi dalam suatu proyek;

2. Menghindari pemborosan sumber-sumber daya, yaitu menghindari pelaksanaan kegiatan yang tidak menguntungkan;

3. Mengadakan penilaian terhadap peluang investasi yang ada sehingga dapat memilih alternatif kegiatan yang paling menguntungkan;

4. Menentukan prioritas investasi.

\section{Aspek-Aspek Analisa Keayakan Usaha}

Adapun aspek yang akan dinilai dalam melakukan studi kelayakan usaha secara umum meliputi:

1. Aspek Teknik;

2. Aspek Finansial;

3. Aspek Pasar/pemasaran;

4. Aspek Hukm/legalitas;

5. Aspek Manajemen/Organisasi;

6. Aspek Ekonomi/Sosial;

7. Aspek Lingkungan;

8. Aspek Yuridis.

\section{E. Pengertian Aspek Finansial}

Beberapa penjelasan dari perhitungan analisis kelayakan diantaranya adalah:

1. Payback Period (PP)

Payback Period menurut Dian Wijayanto (2012:247) adalah periode yang diperlukan untuk menutup kembali pengeluaran investasi (initial cash investment).

$$
\text { Payback Period }=\frac{\text { Nilai Investasi }}{\text { Kas Masuk Bersih }}
$$

Dengan catatan: Rumus ini mengasumsikan bahwa besarnya kas masuk bersih adalah sama pada setiap periode atau sama pada setiap tahunnya. 
2. Net Present Value (NPV)

NPV merupakan selisih antara pengeluaran dan pemasukan yang telah didiskon dengan menggunakan social opportunity cost of capital sebagai diskon faktor.

$$
N P V=\sum_{t=1}^{N} \frac{R_{t}}{(1+i)^{t}}
$$

Keterangan:

NPV = Net Present Value (dalam

Rupiah)

$\mathrm{Ct}=$ Arus Kas per Tahun pada periode $\mathrm{t}$

$\mathrm{C} 0=$ Nilai Investasi awal pada tahun ke 0 (dalam rupiah)

$\mathrm{r}=$ Suku Bunga atau discount Rate (dalam \%)

3. Internal Rate of Return (IRR)

IRR merupakan suku bunga yang akan menyamakan jumlah nilai sekarang dari penerimaan yang diharapkan diterima (present value of future proceed) dengan jumlah nilai sekarang dari penegeluaran untuk investasi. Besarnya nilai sekarang dihitung dengan menggunakan pendekatan sebagai berikut:

$$
I R R=i_{1}+\frac{N P V_{1}}{\left(N P V_{1}-N P V_{2}\right)}\left(i_{2}-i_{1}\right)
$$

4. Rasio manfaat biaya (BCR) adalah rasio yang digunakan dalam analisis biaya dan bermanfaat untuk merangkum hubungan keseluruhan antara biaya relatif dan manfaat dari usaha yang diusulkan.BCR dapat dinyatakan dalam istilah moneter atau kualitatif. Jika suatu proyak memiliki BCR lebih besar dari 1,0. Usaha diharapakan memiliki nilai sekarang yang positif bagi investornya. Rasio manfaat BCR paling sering digunakan dalam penganggaran modal untuk menganalisis nilai keseluruhan dari keuangan dalam melakukan usaha baru. Namun analisis biaya bermanfaat untuk usaha-usaha besar mungkin kesulitan dalam melakukan analisisnya dengan detail karena ada begitu banyak asumsi dan ketidakpastian yang sulit diukur inilah sebabnya ada berbagai hasil BCR potensial.

$$
N E T B / C=\frac{\sum_{t=1}^{n} \frac{B_{t}-C_{t}}{(1+i)^{t}}}{\sum_{t=1}^{n} \frac{C_{t}-B_{t}}{(1+i)^{t}}}
$$

Keterangan:

$\mathrm{B}_{\mathrm{t}}=$ Manfaat (Benefit) pada tahun ke- $\mathrm{t}$

$\mathrm{C}_{\mathrm{t}}=$ Biaya $($ Cost $)$ pada tahun ke-t

$\mathrm{i}=$ Discount Factor

$\mathrm{t} \quad=$ Umur proyek

Indikator $N E T B / C$ Ratio adalah:

- Jika Net B/C > 1, maka proyek layak (go) untuk dilaksanakan.

- Jika Net B/C < 1, maka proyek tdk layak (not go) untuk dilaksanakan.

5. Revenue/Cost $(\mathrm{R} / \mathrm{C})$

Revenue cost adalah besaran nilai yang menunjukkan perbandingan anatara penerimaan usaha dengan total biaya. Revenue dapat diartikan sebagaiBesar Pendapatan kotor, sedangangkanCost adalah biaya keseluruhan.

$$
R / C=\text { Revenue } / \text { Cost }
$$

6. Benefit/Cost $(\mathrm{B} / \mathrm{C})$

Ratio Benefit/Cost (B/C) adalah analisis bisnis untuk memberikan gambaran kenapa harus memilih atau tidak memilih spesifikasi dari suatu investasi (Keen, 2011). Dalam batasan besaran nilai $\mathrm{B} / \mathrm{C}$ Ratio dapat diketahui apakah suatu usaha menguntungkan atau tidak menguntungkan.

$$
B / C=\text { Benefit } / \text { Cost }
$$

7. ROI (Pengembalian Investasi) mengukur keuntungan atau kerugian yang dihasilkan dari investasi relatif terhadap jumlah uang yang diinvestasikan. ROI biasanya dinyatakan sebagai persentase dan biasanya digunakan untuk keputusan keuangan pribadi, untuk membandingkan profitabilitas perusahaan atau untuk membandingkan efisiensi berbagai investasi.

$$
\mathrm{ROI}=\mathrm{B} / \mathrm{C} \text { X } 100 \%
$$


III. METODE PENGUKURAN

\section{DAN TEKNIK}

Berdasarkan tinjauan pustaka, maka dapat disusun kerangka fikir dalam penelitian ini seperti pada gambar berikut ini:

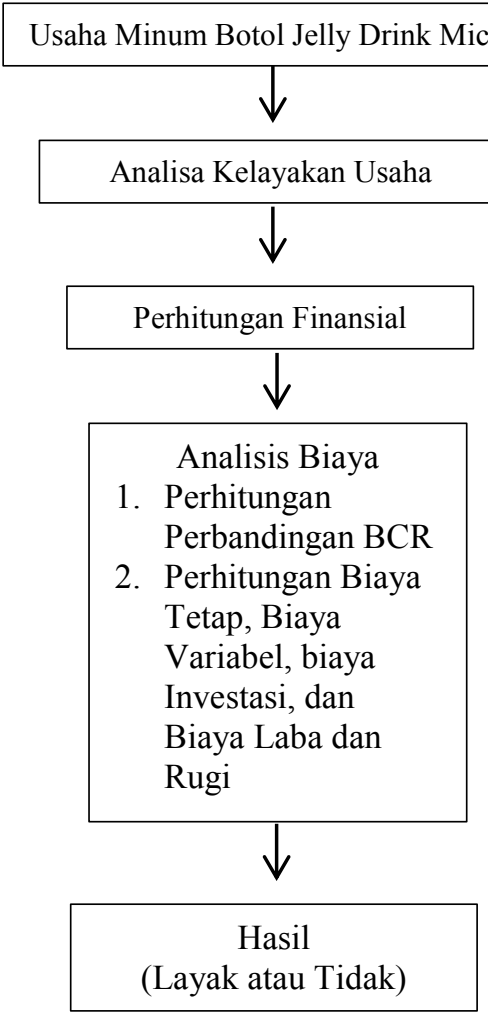

Gambar 1. Kerangka Berfkir (Sumber: Pengolahan Sendiri dari Berbagai Sumber)

Penelitian ini dilakukan di produksi rumahan yang berada di lokasi J1. Gang mede 2 Pamulang barat Tangerang Selatan. Waktu penelitian dilakukan dari bulan September 2018 sampai September 2019.

Dalam pengumpulan data, penulis akan mengambil data penjualan selama kurang lebih satu tahun dengan ketentuan tingkat masalah yang sedang dihadapi apakah terjadi penurunan atau ketidakseimbangan penjualan yang saat ini sedang dilakukan. Penulis menggunakan tiga cara metode pengumpulan data yang dibutuhkan untuk penulisan ini:

1. Observasi yaitu mengadakan secara langsung aktifitas kegiatan perusahaan.

2. Wawancara yaitu dengan cara datang dan mewawancarai langsung pihak perusahaan yang bersangkutan.

3. Pengumpulan data primer.

4. Analisis Biaya dengan menggunkan analisis biaya

\section{HASIL DAN PEMBAHASAN}

\section{A. Analisis Data}

Untuk mengetahui suatu usaha layak atau tidaknya dijalankan, maka perlu adanya sebuah analisa baik dari segi pemasaran, investasi dan keuangannya. Ada beberapa yang perlu di perhitungkan untuk menentukan sebuah usaha tersebut layak dan tidak layak untuk di lanjutkan yaitu dengan cara melakukan pengukuran kinerja finansial. Sebelum ketahap perhitungan biaya tetap, modal, laba dan rugi, PP(PaybackPeriode), NPV (Net Present Value), IRR (Internal rate Rasio), dan BCR (Benefit Cost Rasio), serta menentukan layak atau tidaknya usaha di jalankan berdasarakan analisis biaya dan pengukuran kinerja finansia.

Berikut Tabel 4.1 data penjualan UKM Dapur Gadis Minuman Jelly Drink Michu Pamulang Barat dari bulan September 2018 sampai dengan bulan September 2019.

Tabel 4.1 Data Penjualan Minuman Jelly Drink

\begin{tabular}{|l|l|c|c|}
\hline \multicolumn{4}{|c|}{$\begin{array}{c}\text { Data Alkumulasi Bulaman Penjualan Periode } \\
\text { September } 2018 \text {-Agustus 2019 }\end{array}$} \\
\hline No & Bulan Tahun & $\begin{array}{c}\text { Pemasukan } \\
\text { (Rupiah) }\end{array}$ & $\begin{array}{c}\text { Total Produksi } \\
\text { (botol) }\end{array}$ \\
\hline 1 & September 2018 & 4.000 .000 & 500 \\
\hline 2 & Oktober 2018 & 4.000 .000 & 500 \\
\hline 3 & November 2018 & 4.000 .000 & 500 \\
\hline 4 & Desember 2018 & 4.000 .000 & 500 \\
\hline 5 & Januari 2019 & 4.000 .000 & 500 \\
\hline 6 & Febuari 2019 & 4.000 .000 & 500 \\
\hline 7 & Maret 2019 & 3.648 .000 & 456 \\
\hline 8 & April 2019 & 3.200 .000 & 400 \\
\hline 9 & Mei 2019 & 3.200 .000 & 400 \\
\hline 10 & Juni 2019 & 3.200 .000 & 400 \\
\hline 11 & Juli 2019 & 3.000 .000 & 375 \\
\hline 12 & Agustus 2019 & 2.800 .000 & 350 \\
\hline
\end{tabular}

(Sumber: Pengolahan Data, 2019)

Dari Tabel 4.1 didapat total pendapatan selama satu tahun penjualan yaitu sebesar Rp. 43.048.000 dengan total produksi sebanyak 5.381 botol dalam satu tahun produksi. Dalam satu tahun periode produksi dan penjualan minuman Jelly Drink Michu dilakukan proses produksi selama 3 hari sekali dalam satu bulan proses produksi. Jadi setiap satu bulan hanya di lakukan sekitar 9-10 kali produksi dengan jumlah produk 40-60 botol sekali produksi. Hal ini disebabkan karena faktor SDM yang kurang memadai dan setiap kali produksi hanya 
ditargetkan untuk satu outlet dan pemesananpemesanan di luar PO (Pre Order). Maka dapat ditarik kesimpulan bahwa dalam satu tahun 12 bulan UKM Dapur Gadis memproduksi 6.041 botol dalam satu tahun dengan rata-rata produksi 50 botol setiap tiga hari sekali dalam satu bulan.

Kemudian dari data penjualan diatas akan dijabarkan biaya tetap, biaya variabel, perhitungan pendapatan, biaya penerimaan, total biaya produksi, kemudian membandingkan biaya produksi dengan pendapatan untuk menentukan hasil apakah usaha layak atu tidak dilakukan. Biaya biaya tersebut dapat dijelaskan berikut:

1. Biaya Tetap. Biaya Tetap adalah (Fixed Cost) adalah biaya yang dikeluarkan oleh industri minuman jelly drink Michu yang penggunaannya tidak habis dalam satu masa produksi. Yang termasuk dengan biaya tetap adalah biaya penyusutan peralatan, biaya bangunan dan biaya perawatan.

2. Biaya Penyusutan. Biaya penyusutan peralatan adalah biaya yang tidak akan habis dengan masa pakai dalam kurun waktu tertentu dalam hal artian memiliki sebuah nilai investasi yang tidak akan habis dalam setiap kali produksi. Berikut ini adalah data berkaitan dengan biaya fasilitas produksi. Alat-alat yang disajikan dalam tabel 4.2 tentang biaya Penyusutan peralatan untuk memproduksi jelly drink Michu.

Tabel 4.2 Biaya Penyusutan Peralatan

\begin{tabular}{|c|l|c|c|c|}
\hline \multicolumn{5}{|c|}{ Biaya Penyusutan Peralatan } \\
\hline No & $\begin{array}{c}\text { Nama } \\
\text { Barang }\end{array}$ & Volume & $\begin{array}{c}\text { Harga } \\
\text { Satuan } \\
\text { (Rp) }\end{array}$ & $\begin{array}{c}\text { Jumlah } \\
\text { (Rp) }\end{array}$ \\
\hline 1 & $\begin{array}{l}\text { Kompor } \\
\text { gas }\end{array}$ & 1 unit & 250.000 & 250.000 \\
\hline 2 & $\begin{array}{l}\text { Tabung } \\
\text { gas }\end{array}$ & 1 unit & 150.000 & 150.000 \\
\hline 3 & Regulator & 1 unit & 100.000 & 100.000 \\
\hline 4 & Baskom & 2 unit & 15.000 & 30.000 \\
\hline 5 & Corong & 1 unit & 15.000 & 15.000 \\
\hline 6 & Pisau & 1 unit & 10.000 & 10.000 \\
\hline 7 & $\begin{array}{l}\text { Tempat } \\
\text { sampah }\end{array}$ & 1 unit & 15.000 & 15.000 \\
\hline 8 & Lampu & 1 unit & 35.000 & 35.000 \\
\hline 9 & Sendok & 3 unit & 5.000 & 15.000 \\
\hline 10 & $\begin{array}{l}\text { Cetakan } \\
\text { jelly }\end{array}$ & 5 unit & 5.000 & 25.000 \\
\hline 11 & Talenan & 1 unit & 10.000 & 10.000 \\
\hline 12 & Blander & 1 unit & 250.000 & 250.000 \\
\hline 13 & $\begin{array}{l}\text { Kulkas } f y \\
\text { emzer }\end{array}$ & 1 unit & 1.800 .00 & 1.800 .000 \\
\hline & \multicolumn{2}{|c|}{ Total } & $\mathbf{2 . 7 0 5 . 0 0 0}$ \\
\hline & & & \\
\hline
\end{tabular}

(Sumber, Pengolahan Data, 2019)
Dari Tabel 4.2 didapat biaya penyusutan untuk peralatan yaitu sebesar $\mathrm{Rp}$. 2.705.000,-.

3. Biaya Over Head. Biaya Over Head adalah biaya yang tidak dapat dikaitkan secara langsung dengan pembuatan atau produksi suatu produk atau jasa. Dan biaya Over Head cukup berperan penting demi kelangsungan hidup suatu bisnis atau perusahaan. Data-data yang berkaitan dengan biaya Over Head dapat dilihat pada Tabel 4.3 Biaya Over Head UKM Dapur Gadis Michu Pamulang Barat berikut:

Tabel 4.3 Biaya Over Head

\begin{tabular}{|c|c|c|c|}
\hline \multicolumn{4}{|c|}{ Biaya Over Head/satu Bulan } \\
\hline No & Nama & Satuan & Harga Satuan \\
\hline 1 & $\begin{array}{c}\text { Kontrakan } \\
\text { Rumah } 3 \text { Petak }\end{array}$ & bulan & 750.000 \\
\hline 2 & Sampah & bulan & 20.000 \\
\hline 3 & Listrik & bulan & 150.000 \\
\hline \multicolumn{3}{|c|}{ Total } & 920.000 \\
\hline
\end{tabular}

(Sumber, Pengolahan Data, 2019)

Pada Tabel 4.3 maka didapat biaya Over Head Pabrik sebesar Rp. 920.000,- untuk setiap 1 bulan.

a. Biaya Variabel, untuk biaya ini dapat diambil berdasarkan produksi sesuai dengan kebutuhan biaya material, biaya bungkusnya / kemasanya, karyawan, transportasi, bahan bakar dan biaya lain-lainya, sesuai dengan UKM Jelly Drink di Pamulang Barat.

b. Biaya Bahan Baku (row material cost). Berikut ini adalah data yang berkaitan dengan biaya bahan baku. Didapat biaya bahan baku yaitu sebesar Rp. 1.040.000,- setiap kali produksi dalam satu bulan dengan estimasi 10 kali belanja dengan memproduksi 50 botol/produksi.

c. Biaya Tenaga Kerja Langsung

Berdasarkan hasil observasi saat ini UKM Dapur Gadis Michu Jelly Drinkmempekerjakan tenaga kerja sebanyak 2 orang dengan kapasitas produksi minuman 50 botol perharinya, didapat biaya tenaga kerja yaitu sebesar Rp. 500.000,- per bulan untuk 10 kali produksi 2 orang pekerja.

d. Biaya Front of House (FOH) 
Berikut ini adalah data yang berkaitan dengan biaya Front of House (FOH), didapat biaya Front of House yaitu sebesar Rp. 1.007.500,- per bulan dengan total 10 kali belanja.

\section{B. PENGUKURAN KINERJA FINANSIAL}

Pengukuran Kinerja Finansial, yaitu diantaranya sebagai berikut:

1. Biaya Produksi

Biaya Produksi adalah perhitungan keseluruhan biaya yang digunakan pada saat proses Produksi. Yang termasuk dengan biaya produksi adalah dimulai dari biaya bahan baku, biaya tenaga kerja, biaya over head, biaya fron of house, dapat dilihat pada Tabel 4.4 berukut:

Tabel 4.4 Rancangan Biaya Produksi Michu Jelly Drink

\begin{tabular}{|c|c|c|}
\hline \multicolumn{3}{|c|}{ Rancangan Biaya Produksi } \\
\hline No & Uraian & Harga (Rp) \\
\hline 1 & Biaya Bahan Baku & 104.000 \\
\hline 2 & $\begin{array}{c}\text { Biaya Tenaga } \\
\text { Kerja }\end{array}$ & 50.000 \\
\hline 3 & $\begin{array}{c}\text { Biaya Front Of } \\
\text { House }\end{array}$ & 100.750 \\
\hline \multicolumn{2}{|r|}{ Total } & 254.750 \\
\hline
\end{tabular}

(Sumber: Pengolahan Data, 2019)

Dari Tabel 4.4 maka didapat Total Biaya Produksiyaitu sebesar Rp. 254.750,-/ produksi.

a. Kapasitas Produksi

Kapasitas Produksi Jelly Drink Michu UKM Dapur Gadis setiap satu kali produksi adalah:

1) Botol Kale Plastik :50 botol

2) Bubuk Minuman : 2 bungkus $/ \mathrm{kg}$

3) Berat Isi Kemasan : $350 \mathrm{ml}$

4) Kapasitas Produksi :50 botol/produksi

Dari perhitungan diatas kapasitas produksi Jelly Drink Michu UKM Dapur Gadis Pamulang Barat setiap satu kali produksi adalah 50 botol, dengan keterangan UKM Dapur Gadis Pamulang memproduksi setiap 3 hari sekali dengan total 10 kali produksi dalam satu bulan, dan dalam satu tahun terhitung 6.041 botol.

b. Analisis Pendapatan

Hasil pendapatan produksi minuman botol jelly drink Michu, Dapur Gadis:

Produksi minuman botol jelly drink $/$ produksi $=50$ botol
1) Biaya Produksi

$=$ Rp. $254.750: 50$ botol

$=$ Rp. $5.095,-/$ botol

Total Jumlah (Botol) Produksi/bln

$=50$ botol X 10 (produksi/bulan)

$=500$ botol

Total Biaya Produksi 500 Botol / bulan

$=500$ X Rp. 5.095,-

$=$ Rp. Rp. 2.547.500,-/bln

2) Harga penjualan/botol dengan estimasi keuntungan $50 \%$

$=(50 \% \mathrm{X}$ Biaya $\quad$ produksi $)+$ biaya produksi

$=(50 / 100 \times$ Rp. 5.095$)+$ Rp. $\quad 5.095$

$=$ Rp. 7.642,5,-/botol

$=$ Rp. $8.000,-/$ botol

Dapat ditarik kesimpulan bahwa harga jual setiap satu botol minuman jelly drink Michu adalah Rp. 8000,- dengan estimasi keuntungan $50 \%$ dan dengan penjualan 500 setiap bulan, dimana setiap satu kali produksi hanya memproduksi 50 botol.

1) Analisis Penerimaan

Pendapatan merupakan total nilai produksi dari usaha dalam jangka waktu tertentu dikali dengan harga jual. Besar Pendapatan Kotor yang diterima yaitu Rp. 4.000.000,-/bulan, dengan keterangan satu bulan hanya memproduksi 10 kali produksi dan total produksi 500 botol dalam satu bulan. Nilai Produk didapatkan dengan mengkali Nilai produk/hari dengan 10 kali produksi dalam satu bulan. Untuk menentukan hasil rata-rata pendapatan dari satu tahun yaitu dengan mentotal pendapatan satu tahun dibagi dengan 12 bulan. Kemudian untuk rata-rata penerimaan satu bulan adalah sebesar;

Rata-Rata Pendapatan

$=$ Rp. 43.048.000/12

$=$ Rp. 3.587.333,-/bulan

Jadi kesimpulan dari rata-rata penerimaan penjualan Michu UKM Dapur Gadis Pamulang Barat adalah sebanyak Rp. 3.587.333,-/bulan.

2. Analisis Keuntungan (Benefit)

Keuntungan memberi tahu kita apakah suatu skema benar-benar bermanfaat secara keseluruhan. Angka ini, disajikan sebagai nilai bersih sekarang dan merangkum semua. Rata rata 
keuntungan pada usaha produksi minuman Jelly Drink Michu dapat dilihat pada Tabel 4.5 berikut:

Tabel 4.5 Keuntungan

Produksi Minuman

\begin{tabular}{|c|c|c|}
\hline \multicolumn{3}{|c|}{ Rancangan Biaya Produksi } \\
\hline No & Uraian & $\begin{array}{c}\text { Harga } \\
\text { (Rupiah) }\end{array}$ \\
\hline 1 & $\begin{array}{l}\text { Total Penerimaan } \\
\text { (TR) }\end{array}$ & 3.587 .333 \\
\hline 2 & $\begin{array}{l}\text { Total Biaya } \\
\text { Produksi }\end{array}$ & 2.547 .500 \\
\hline & Total & 1.039 .833 \\
\hline
\end{tabular}

(Sumber, Pengolahan Data, 2019)

Berdasarkan Tabel 4.5 total penerimaan usaha minuman Jelly Drink Michu UKM Dapur Gadis Pamulang Barat sebesar Rp. 3.587.333,-/bln dengan produksi $10 \mathrm{kali} / \mathrm{bln}$,sedangkan total biaya produksi sebesar Rp. 2.547.500,/bln dengan produksi $500 \mathrm{btt} / \mathrm{bln}$. Jadi dalam perhitungan total biaya produksi dengan perhitungan keuntungan dikurangi jumlah total biaya produksi sehingga didapat sebesar Rp $1.039 .833,-$ / bulan.

\section{ANALISIS KELAYAKAN USAHA}

Untuk memperhitungkan suatu usaha layak atau tidaknya dijalankan perlu adanya perhitungan dan perbandingan, diantaranya yaitu:

1. Revenue/cost (R/C) Rasio

Pengertian dari rasio perhitungan ini adalah perbandingan dari hasil besaran nilai yang menunjukan penerimaan usaha dengan total biaya, sehingga dapat dinyatakan sebagai berikut:

$\mathrm{R} / \mathrm{C}=$ Revenue (Rata-rata Total Pendapatan) / Cost (Biaya Produksi)

$$
=3.587 .333 \div 2.547 .500=1,40
$$

Sehingga UKM Jelly Drink Dapur Gadis Pamulang Barat dalam perbandinganya penerimaan total biaya Memiliki nilai rasio sebesar Rp 1,40 > 1 sehingga dapat dikatakan setiap pengeluaran Rp. 100,memberikan penerimaan sebesar Rp. 140 maka usaha minuman Jelly Drink Michu
UKM Dapur Gadis Pamulang Barat layak untuk diusahakan.

\section{Benefit/Cost (B/C) Rasio}

Benefit/Cost $(B / C)$ rasio adalah analisis bisnis untuk memberikan gambaran kenapa harus memilih atau tidak memilih spesifikasi dari suatu investasi. Dalam batasan besaran nilai B/C (Benefit/Cost) ratio dapat diketahui apakah menguntungkan atau rugi. Dapat dilihat sebagai berikut:

$\mathrm{B} / \mathrm{C}=$ Benefit $($ Total Keuntungan Kotor $) \div$ Cost (Biaya Produksi)

$$
\begin{aligned}
& =1.039 .833 \div 2.547 .500 \\
& =0,40
\end{aligned}
$$

Berdasarkan perbandingan total keuntungan (Benefit) dan total biaya (Cost) menunjukkan bahwa perhitungan $\mathrm{B} / \mathrm{C}$ (Benefit/Cost) rasio pada UKM Dapur Gadis Michu Pamulang Barat yaitu menguntungkan karena nilai $\mathrm{B} / \mathrm{C}$ rasio $\mathrm{Rp}$. $0,40>0$. Artinya setiap biaya produksi yang dikeluarkan sebesar Rp. 100,- maka akan diperoleh keuntungan sebesar Rp. 0,40 menunjukkan bahwa usaha minuman Jelly Drink Michu UKM Dapur Gadis Pamulang Barat dapat dikatakan layak (untung) untuk diusahakan. Hal ini dapat dilihat dari perbandingan total laba kotor dengan total biaya produksi yang lebih besar dari nol.

3. Return On Investment (ROI)

Return On Investment (ROI) adalah salah satu bentuk dari rasio profitabilitas yang dimaksudkan untuk mengukur kemampuan perusahaan dengan keseluruhan dana yang ditanamkan dalam aktiva yang digunakan untuk operasinya perusahaan untuk menghasilkan keuntungan.

ROI $=($ Benefit (Total Keuntungan Kotor)

$\div$ Cost (Biaya Produksi)) $\times 100 \%$

$=(1.039 .833 \div 2.547 .500) \times 100 \%$

$=0,40 \times 100 \%$

$=40 \%$

Berdasarkan perbandingan laba dan modal produksi diperoleh nilai ROI sebesar $40 \%$, yang berarti bahwa besarnya keuntungan yang diperoleh dibandingkan investasi (ROI) besarnya keuntungan yang diperoleh dibandingkan dengan investasi yang 
ditanamkan adalah baik, artinya setiap modal sebesar Rp. 100,- diperoleh keuntungan sebesar Rp. 40,-.

\section{KESIMPULAN}

Dari hasil pengolahan data dan perhitungan pada penelitian ini, berdasarkan perhitungan aspek finansial analisis kelayakan usaha pada UKM Jelly Drink Dapur Gadis Michu di Pamulang Barat dapat dilihat pada rangkuman berikut:

1. Hasil dari perhitungan berdasarkan perbandingan nilai Revenue / Cost (RC) memiliki nilai sebesar $\mathrm{Rp} 1,40>1$ rasionya. Sehingga dalam perbandingan rasio Usaha Jelly Drink ini dalam setiap pengeluaran $\mathrm{Rp} 100$,- dan dalam penerimaan dengan jumlah $\mathrm{Rp} 140$ sehingga dapat disimpulkan bahwa Usaha Minuman Jelly Drink yang terletak di Pamulang barat ini dinyatakan layak dalam usahanya.

2. Hasil dari perhitungan rasio benefit atau keuntungan dari total biaya (cost) dengan biaya produksi pada UKM Dapur Gadis di Pamulang Barat mempunyai nilai sebesar $\mathrm{Rp} 0,40>0$. Sehingga dalam pengeluaran produksi sebesar Rp 100,dan dapat dikatakan keuntungan sebesar Rp 0,40. Maka dilihat dari keuntungan UKM Dapur Gadis di Pamulang Barat dalam memproduksi Minuman Jelly Drink dinyatakan layak untuk usaha, dikarenkan menguntungkan.

3. Dari perhitungan yang diperoleh dari perbandingan laba dan modal produksi dengan nilai keuntungan ROI investasi maka setiap investasi yang ditanamkan memberikan keuntungan sebesar Rp 40,dari mudal pertama dengan jumlah sebesar Rp 100,-. Untuk itu dapat disimulkan bahwa modal dari nilai ROI sebesar $40 \%$ dan Usaha Minuman Jelly Drink Dapur Gadis yang terletak di Pamulang Barat dinyatakan baik dan layak.

\section{DAFTAR PUSTAKA}

Andriyanto, Irsad dan Nurjanah. 2015. Strategi Klaster Industri Menghadapi Pasar Global. Jurnal Bisnis dan Manajemen Islam. Vol. 03 Nomor 01. Juni. hal. 85114.

Harnanto, 2015. Akuntasi Biaya. Andi Publisher. Yogyakarta. Hlm 217

Hasnawati. 2016. Analisis Keuntungan Dan Kelayakan Usaha Pembuatan Tahu Di Kelurahan Liabuku Kecamatan Bungi Kota Bau-Bau. Kendari:UniversitasHalu Oleo.

Kasmir, Jakfar. 2017. Studi Kelayakan Bisnis. Kencana. Depok. Cetakan ke-13.

Sajari, Ibnu. 2017. Analisis Kelayakan Usaha Keripik Pada UD. Mawar di Gampong Batee Ie Liek Kecamatan Samalanga Kabupaten Bireuen. Jurnal Sains Pertanian 1.1. Bireuen

Umar, Husein. 2010. Manajemen Perusahaan. Gramedia Pustaka Utama. Jakarta

Winantara, I. Made Yogi, A. B. U. Bakar, and Ratna Puspitaningsih. 2014 Analisis Kelayakan Usaha Kopi Luwak di Bali. Reka Integra 2.3. Bandung

Wulandari, P. T. (2012). Analisis kelayakan finansial pengembangan usaha kecil menengah (UKM) nata de coco di Sumedang, Jawa Barat. Asian Journal of Innovation and Entrepreneurship, 1(02), 113-120. 